\title{
Significant Role of Fish Nutrients with Special Emphasis to Essential Fatty Acid in Human Nutrition
}

\author{
Pooja Badoni* , Iqra Nazir, Merenlong Aier, Puspendu Bikash Maity, Subhadeep \\ Samanta and Animesh Das
}

Department of Fisheries, Doon PG College-Uttarakhand-248007, India

*Corresponding author

\section{A B S T R A C T}

\section{Keywords}

Fish, Human health, Nutritional value, Immunity, Food security

\section{Article Info}

\section{Accepted:}

17 January 2021

Available Online:

10 February 2021

\begin{abstract}
A balanced diet containing all the essential nutrients is necessary to build a good health. Fish in this context, is a healthy food being rich in essential nutrients like quality animal proteins, polyunsaturated fatty acids (PUFA) especially the $\omega-3$ PUFA and micronutrients. According to WHO, "Nutrition is the intake of food, considered in relation to the body's dietary needs". The ultimate goal is to promote optimal health and reduce the risk of chronic diseases such as cardiovascular disease and cancer as well as to prevent classic nutritional deficiency diseases. Apart from this, fish are more available and affordable than other animal proteins sources in tropical countries. Fish proteins have immunoglobulin that act as defence mechanism against viral and bacterial infections and prevent protein calorie malnutrition. The lipids of fishescontainn-3 PUFA like EPA and DHA that not only maintains the blood pressure but also helpful in preventing the cardiovascular diseases. Iron helps in haemoglobin synthesis and prevents the occurrence of anaemia. Selenium is important for the function of the thyroid gland. Calcium and vitamin D naturally present in fishes prevent the rickets. Vitamin A helps to maintain the normal vision and normal immune system.
\end{abstract}

\section{Introduction}

Being exclusively aquatic and cold blooded vertebrates with streamlined body and lateral line sense organs Verma and Prakash (2020). Fishes occur both in marine and fresh water and are good source of both macro (such as proteins, lipids, ash) and micro nutrients (such as vitamins and minerals). The nutrients are essential for good health Srivastava and Srivastava (2008) and better life as they provide energy and involved in repair and regulation processes. The moisture, protein, lipids, vitamins and minerals are important macro and micro nutrients that are providing nutritional value to the fish meat Kumar et al., (2020). Essential nutrients especially proteins of high biological values and fats, so it is often 
referred to as rich food for poor people Sujatha et al., (2013)are provided by the fish. Protein and fats are the major nutrients of fish which determine the nutritional value of fish. High quality protein, fats, vitamins and minerals like magnesium and phosphorus are the important nutritive contents that is provided by fishes Ali et al., (2020) Fishes are better than other animal foods as they contain both macro and micro nutrients in fish, Apart from being food source, fish also functions to prevent human being from variety of diseases in the world. Fish improves the overall nutritional quality of a mixed diet Pawar and Sonawane (2013) as fish proteins have essential amino acids and only $140 \mathrm{gm}$ of fish can fulfill the 50-60\% daily requirement of quality proteins in human beings. Fishes are also rich in micronutrients which tend to be more easily available than those from plant food. As compared to land living animals, fishes are rich sources of protein and have a high content of omega-3 long chain poly unsaturated fatty acids. Fishes are the cheapest source of animal protein. Ensuring about 20\% of protein intake to a third of the world's population which is more evident in developing countries Bene et al., (2007)fish proves to be a healthy food and is a major player in human nutrition. As far as global biodiversity hotspot is considered, India is harbouring more than $10 \%$ of the global fish diversity and thereby has the potential to fulfil the daily needs of the essential nutrients that are significant for human health and also provides food and nutritional security Mohanty et al., (2019). On a fresh weight basis, fish contains a good quantity of protein about $13-20 \%$ and contains all the essential amino acids. The fat content of fish ranges from 0.2 to $15 \%$ and it varies depending on the species as well as the season in general and fish has less fat than red meats. Fat from fish species are essential for growth of children and prevents the occurrence of cardiovascular diseases such as coronary heart diseases Calder(2004) as theycontain the poly unsaturated fatty acids (PUFA) especiallyw-3 fatty acids viz., EPA (eicosapentaenoic acid) and DHA (docosahexaenoic acid)., In proper brain development among unborn babies in pregnant women and preventing preterm delivery and low birth weight Mohanty et al., (2016) and Giri et al., (2010) PUFA present in fishes plays a very significant role and apar from this Fish also plays an important role in human nutrition as an efficient vehicle to deliver health promoting long chain $\omega-3$ polyunsaturated fatty acid (PUFA) in the diet Sargent (1997). Micronutrients like vitamins and minerals are also present in the fish muscle. The micronutrients prevent many disorders due to deficiency of such micronutrients and fulfil the hidden hunger of human population Mohanty et al., (2016a). The high nutritional value of fish is mainly associated with digestible protein which is an excellent source of EAA Sanchez-Alonso (2007). Fish protein occupies an important position in human nutrition Nargis (2006). FAO (2014) reported that $50-60 \%$ of an adult's daily protein requirements are fulfilled by consuming $150 \mathrm{~g}$ of fishflesh. Some information are available on nutrient composition of Indian major carp Paul (2016), catfish Paul et al., (2015) and Freshwater fish Paul et al., (2019).

\section{Beneficial role of fishes in human diet}

The nutritional properties of fish and fish products render them valuable foodstuffs that are beneficial for human health. Fish and fish products play tremendous part in the nutritional picture because they are rich source of nutrients and provide a good balance of protein, vitamins and minerals, and a relatively low caloric content. In addition these properties it also excellent sources of Polyunsaturated fatty acids which appear to have beneficial effects in reducing the risk of cardio-vascular diseases and are linked with 
positive benefits in many other pathological conditions particularly, certain types of cancer and arthritis. Pal et al., (2018). Almost all the minerals present in fish which is required our body. The minerals present in fish iron $(\mathrm{Fe})$, Calcium (Ca), Zinc (Zn), Phosphorus (P), Selenium (Se), Fluorine (F), Iodine (I). These minerals are with high bioavailability; they can easily absorbed by the body. In this review up-to-date information about importance of fish in human nutrition and beneficial effect of essential fatty acid in human health is also reviewed. The demand for high quality fish and fishery products is growing significantly every year mostly due to their nutritional fact that they contain plentiful of beneficial healthy substances FAO (1986). The most important of these are fish lipids, which usually contains high amount of omega3 fatty acids, mainly $\alpha$-linolenic acid, eicosapentaenoic acid (EPA), and docosahexaenoic acid (DHA). The omega-3 fatty acids have several beneficial impacts on human health. These include decreasing the risk of myocardial infarction Bucher et al., (2002) lowering blood pressure and triglyceride concentration in blood [26] enhancing the immune system Damsgaard et al., (2007) and sustaining proper brain function in human body. They also protect against various psychological disorders, and cancer Caygill and Hill (1995). Fish is one of the most important foods in human diet because of its high nutritional quality. They are the well-known source of a group of polyunsaturated fatty acids (PUFAs) especially omega-3 and omega-6, which can prevent atherosclerosis and thrombosis. They are also rich source of fat-soluble and B-group vitamins Erkan and Bilen (2010). These fatty acids have preventive effects on coronary heart diseases, autoimmune disorders, arrhythmias, lowering plasma triglyceride levels and blood pressure. Nevertheless, fatty acids are not the only important nutrients in the fish and fishery products, it is also a good source of easily digestible protein, and its amino acid profile usually contains most of the essential amino acids which is required to humans for balanced diet. The long-chain, polyunsaturated fatty acids (LC-PUFAs; acids comprising 20 or more carbon atoms and at least three double bonds) are the major components of cellular membranes Graham et al., (2007). The nutritional benefits of fish stem for the most part, from its exceptionally advantageous fatty acids profile. LC-PUFAs play important roles in regulating biochemical and physiological processes. For these reasons LC-PUFAs are numbered among those food ingredients with beneficial human health properties Pond (1998). Fish lipids are practically the only source of EPA and DHA. Fish consumption is also known to have health benefits for adults. Strong evidence underlines how consumption of fish, and in particular oily fish, lowers the risk of coronary heart disease (CHD) mortality. Up to 36 percent reduction in the risk of dying due to coronary heart diseases by long-chain omega-3 fatty acids mainly found in fish and fishery products. CHDs are a global health problem affecting all populations. The Inuit diet contained mainly fat fish and sea animals which have, among other qualities, high levels of EPA and DHA Connor (2000). EPA and DHA display several properties advantageous for human health. In addition to reducing the risk of some cardiovascular diseases Calo et al., (2005) and cancers Wolk et al., (2006), they can improve various functions in the human organism Berbert et al., (2005). A daily intake of $250 \mathrm{mg}$ EPA+DHA per adult gives optimal protection against Coronary heart disease. For optimal brain development in children, the daily requirement is only 150 mg per day. This is particularly important as brain disorders are increasing dramatically, and in the developed part of the world the cost related to mental disorders is now greater than the cost related to CHD and cancer combined. Wild and responsibly farmed fish are a healthy 
and good alternative to meat products, Fisheries products are known to be easily digestible, ensuring that a high percentage of the nutrients are actually benefiting the consumer.

\section{Contribution of fish as source of essential nutrients}

Fish and fishery products have traditionally been regarded as a good source of protein, but more and more emphasis is now being placed on their role in providing long chain omega- 3 fatty acids and also on being a rich source of vitamins and minerals deficient in many local diets. Micronutrient deficiencies are affecting hundreds of millions of people, particularly women and children in the developing world. More than 250 million children worldwide are at risk of vitamin A deficiency, 200 million people have goiter, and 20 million are mentally retarded as a result of iodine deficiency, 2 billion people (over 30 percent of the world's population) are iron deficient affecting particularly women in the developing world, and 800000 child deaths per year are attributable to zinc deficiency. Rural diets in many countries may not be particularly diverse, depending on a large proportion of rice or maize. Thus it is vital to have optional food based sources that can provide all essential nutrients in such diets. According to Balami et al., (2019), various nutrients available in fish are as under (Table 1):

\section{Protein}

Nearly $60 \%$ of people from developing countries depend upon consumption of fish for over $30 \%$ of their animal protein supplies. The unit cost of production of fish as compared to other dietary protein source such as livestock products is much cheaper. It is better than meat protein and although inferior to Milk and egg protein. The value of fish protein is very high having a stable composition of essential amino acids, with slight deficiencies of methionine and threonine and an excess of lysine. The latter amino acid is lacking in cereals. Fish is low in calories as compared to other protein-rich foods such as meat poultry. Because of a low in calorific value and an excellent source of protein, fish helps to maintain a healthy weight Pawar and Sonawane (2013). The fish is a high quality source of protein as it contains almost all essential amino acids. As in terms of digestibility fish muscle is more important than other animal protein due to the presence of lower level connective tissue Ventakaraman and Chezhian, (2015). Amino acid composition and the digestibility of fish proteins are excellent about $85-95 \%$. Fish are regarded as an excellent source of high-quality protein, particularly the essential amino acids lysine and methionine. In addition to the high nutritional value, fish proteins also have good functional properties such as water-holding capacity, gelling, emulsification, and textural properties for the products such as fish mince and surimi, the water-holding capacity and the gelling properties which determine the textural attributes of the products are important quality parameters Venugopal (1995). Proteins are important for growth and development of the body, maintenance and repairing of worn out tissues. Protein content of fish muscle depends on species, nutritional condition and type of muscle.

Fish proteins are having high biological value as they contain all essential amino acid in the right proportional and specially, lysine as well as sulphur containing amino acid such as methionine and cysteine which are absent in plant protein. To improve nutritional status of moderately undernourished children, it is estimated that approximately one-third of protein should be provided by animal-source foods in the diet, so that lysine from animalsource foods can be fully utilised to 
compensate the shortage of lysine in staple foods thereby having a significant impact on their growth parameters Michaelsen et al., (2009).Fats

Fats play an important role in synthesis of hormone, circulation of vitamins and providing energy. The fats are rich in unsaturated fatty acids like MUFA (mono unsaturated fatty acid) and PUFA (poly unsaturated fatty acid) that provide essential fatty acids. Omega-3 fatty acids are found in foods such as fish and flaxseed and in dietary supplements, such as fish oil. The three main Omega-3 fatty acids are alphalinotenic acid (ALA), eicosapentanoic acid (EPA) and docosahexaenoic acid (DHA). ALA is found mainly in plant oils such as flaxseed, soya bean and canola oils while DHA and EPA are found in fish and other seafood Morales et al., (2015). ALA is an essential fatty acid, meaning that human body cannot synthesize it hence it is required to take with foods and beverages. The human body can convert some ALA into EPA and then to DHA, but only in very small amount. Therefore getting EPA and DHA from foods is the only practical way to increase levels of these Omega-3 fatty acids. Omega-3s are important components of the membranes that surround each cell. DHA levels are especially high in retina (eye), brain and sperm cells. Omega-3s also provide calories and have many functions related with heart, blood vessels, lungs, immune system and endocrine organs.

\section{Lipids}

Fish lipids are known to provide high contents of important components for the human diet, such as nutritional lipid-soluble vitamins (A and D) and essential fatty acids $\omega 3$ polyunsaturated fatty acids (PUFA) that have shown a positive role in preventing certain human diseases, like cardiovascular ones Simopoulos (1997). They play an important role in maintaining the integrity of plants and animals as structural compounds by forming a barrier separating the living cell from the outside and they are the major source of cellular energy and function in living organisms where they can be stored. Usually Marine fish lipids, however, differ from the other lipids in that they longer-chain fatty acids, and a larger proportion of highly unsaturated fatty acids Ackman (1989). The lipid content of fish varies depending on the species as well as season but generally, fish have less fat than red meats.

\section{Vitamins}

The entire vitamins essential for human health is present in good amount in fish but amount may vary according to the fish species. Fish is a significant source of vitamin $\mathrm{A}$ and $\mathrm{D}$ and other vitamins of B-group. Many species of fishes store large amount of vitamin $\mathrm{A}$ and $\mathrm{D}$ in their liver. Vitamin A helps for normal growth, formation of bones and teeth, building of cells and it also prevent the problem of poor eyesight and helps in the treatment of many eye diseases Pal et al., (2018). In fishes, the vitamins are synthesized in the skin from 7dehydrocholestrol when exposed to ultraviolet light. It has 3 times higher potential as compared to vitamin D (ergocalciferol). Vitamin D deficiency leads to rickets, osteomalacia and a low bone mineral density (BMD) and increased cases of bone related disorder. It is also connected with diabetes Holick (2008a), (2008b). Vitamin D deficiency causes osteopenia, osteoporosis and fractures in adults. Fish and fish oils contains vitamin D naturally Holick and Chen (2008).Oily fish is a rich source of vitamins A and $\mathrm{D}$, which are important in the growth and development of children. White fish is a good source of B vitamins. Vitamin A is necessary for normal growth, formation of bones and teeth, cell building, it prevents poor eyesight and helps in treatment of many eye diseases. 
Fatty seafood such as mackerel, herring, salmon and trout are all rich in vitamin $\mathrm{A}$ and D. Fish oil taken with vitamin $\mathrm{E}$ reduces levels of inflammation, joint swelling, pain and tenderness characteristic of rheumatoid arthritis. Vitamin $\mathrm{K}$ present in fish is responsible for anti-hemorrhage factor Anon (2017).

\section{Minerals}

Fish is an important source of minerals which are not widely available from other sources in the diets of poor people. In comparison to other minerals, Calcium absorption is insufficient as only $25-30 \%$ of $\mathrm{Ca}$ is absorbed by human body. Besides, milk and milk products, fish and fish bones are good source of $\mathrm{Ca}$. Selenium is toxic in large doses to humans but is important for humans which functions in the form of selenoproteins as a co-factor for reducing the antioxidant enzymes, such as glutathione peroxidase. This also helps for the proper functioning of thyroid gland. Low level of selenium can lead to myocardial infracts, increased risk of cancer and renal disease Holben and Smith (1999). The Calcium absorption from fish is comparable to that of skimmed milk. Calcium is also important for bone density and plays a role in most of the metabolic processes. Fish is very rich in minerals such as iodine and selenium. The consumption of small indigenous species of fish as whole with heads and bones can be excellent source of many minerals such as iodine, selenium, zinc, iron, calcium, phosphorus and potassium.

\section{Essential fatty acid}

Fatty acids are natural components of fats and oils. Unsaturated fatty acids are mainly in fatty fish origin. Polyunsaturated fatty acids (PUFAs), there are two different groups: the 'omega-3and 'omega-6-fatty acids' both are considered as essential fatty acids because they cannot be synthesized by humans so must be obtained from diet Kris-Etherton et al., (2002). They also protect against various psychological disorders, depression and attention deficit hyperactivity disorder in particular and cancer Sinn(2007). Availability of iodine and selenium in marine fish is of special significance from nutritional point of view.

Iodine is important for hormones thyroxin that regulate body metabolism and in children it is required for growth and mental development. Selenium is an essential antioxidant trace element. Iron is important in the synthesis of haemoglobin in red blood cells for transporting oxygen to all parts of the body arthritis.

\section{Fish and Seafood}

On a global basis fish and seafood products constituting the third major source of dietary protein consumed by humans after cereals and milk in 2017 and representing $17.1 \%$ of total animal protein supply (fish and seafood consumption being greater than the consumption of poultry meat, pig meat, bovine meat, or hens eggs; Figure 1A; FAO 2020a). Compared with terrestrial meat products, aquatic animal foods (whether captured or cultured) having a higher protein content on an edible weight basis than most terrestrial meats, a lower caloric density and generally being much leaner than red and processed meats, having the highest content of long chain omega-3 polyunsaturated fatty acids than any other animal foodstuff, and generally having a higher mineral and vitamin content than most terrestrial meats and processed meat products (including vitamins - Vitamin A, Vitamin D, Vitamin E, Vitamin B12, Folic acid, Choline, Coenzyme Q10, and minerals Calcium, Magnesium, Iron, Copper, Zinc, Iodine, Selenium, and trivalent Chromium (Tacon and Metian, 2013; USDA, 2018). 
Table.1

\begin{tabular}{|c|c|c|}
\hline S.NO & Constituent & Percentage (\%) \\
\hline $\mathbf{1}$ & Protein & $16-21$ \\
\hline $\mathbf{2}$ & Lipid & $0.2-25$ \\
\hline $\mathbf{3}$ & Ash (Minerals) & $1.2-1.5$ \\
\hline $\mathbf{4}$ & Moisture & $66-71$ \\
\hline
\end{tabular}

In addition, fish and seafood products have, like any other food products found on the market, been through food safety measures and verification (from national regulations to International food standards) although ensuring food safety and security in a highly globalized world presents increasingly difficult Fukuda (2015). A healthier alternative Fish and seafood (includes all captured and farmed finfish, crustaceans, mollusks, and aquatic plants) offer a much healthier food source than terrestrial meat products (includes processed meats, red meat, poultry) in the global fight against malnutrition and obesity Bogard et al., (2015); FAO (2018); Thilsted et al., (2014); Zhong et al., (2020). All fish are not all created equal It follows from the above discussion that not all fish are created equal, and that their nutritional composition, contaminant burden (if any), and consequently their potential health value, will vary depending upon the fish species, its position in the aquatic food chain and feeding habit, its longevity and size before being consumed, its geographical origin and source (if harvested from a river, lake, estuary, or open sea; recreational fishery, wild caught or farmed), and the nutrient profile and composition of the feed fed if farmed Kwasek et al., (2020); Mohan Dey et al., (2005). Moreover, it is also evident that the rivers and oceans where our wild-fish are being caught or fished are also suffering from an everincreasing torrent of environmental pollutants from wastewater treatment plants, urban and agricultural runoff, and from the air Escher et al., (2020); Johnson et al., (2020); Xanthos and Walker (2017). The net result of this has been the progressive accumulation of many of environmental pollutants within the aquatic food chain, including most of the wild-caught species currently being used as human food Barber et al., (2006); Davis et al., (2004); Klumpp et al., (2002); VKM, (2014). Macro minerals are calcium, phosphorus, magnesium, chloride, sodium, potassium and sulfur. Dietary deficiencies of most macrominerals have been difficult to produce in fish because of the uptake of waterborne ions by the gills. However, it is known that phosphorus is the most critical macromineral in fish diets because there is little phosphorus in water. Phosphorus is a major constituent of hard tissues such as bone and scales and is also present in various biochemicals. Impaired growth and feed efficiency, as well as reduced tissue mineralization and impaired skeletal formation in juvenile fish, are common symptoms when fish have diets deficient in phosphorus, Chloride, sodium and potassium are important electrolytes involved in osmoregulation and the acid-base balance in the body, IodiLall (2002). The micro minerals (also known as trace minerals) include cobalt, chromium, copper ne, iron, manganese, selenium and zinc. Impaired growth and poor feed efficiency are not readily induced with micromineral deficiencies, but may occur after an extended period of feeding deficient diets.

\section{Fish as a source of micronutrients}

While the importance of fish as a source of animal protein and essential fatty acids is well known, little attention has been given to the role of fish as a source of micronutrients. 
Small fish species are rich in micronutrients, in particular, vitamin A, calcium, iron and zinc, as they are consumed whole with bones, heads and viscera where most micronutrients are concentrated. These species are commonly consumed by the poor, and thus have a high potential to address micronutrient deficiencies.

\section{Calcium}

The calcium content of fish is around eight times higher than that of milk, and calcium in fish bones has the same bioavailability as milk Larsen et al., (2000). Therefore, small fish consumed with bones are important as a source of calcium, especially in populations with low intakes of milk and milk products. However, all small fish species have high calcium content such as puti (Puntiusticto) and chanda (Chandaranga), having $>800 \mathrm{mg} / 100 \mathrm{~g}$ raw, edible parts, calculated from plate-waste Roos (2001).Fish bones are very rich in calcium. However, as fish bones are not necessarily eaten, the amount of bones discarded as plate-waste must be adjusted for to obtain the calcium content of the edible parts. Consequently, fish which are not eaten with bones do not contribute to calcium intake.

\section{Iron}

Some fish are rich in iron and it concentrated in the head and viscera, therefore, iron content is determined by cleaning methods such as leaving the head or cutting off it. A serving of the traditional sour soup made with chanwaphlieng (Esomus longimanus), eaten with boiled rice, the most common meal in the study area, supplied $45 \%$ of the daily requirement of iron in women of childbearing age, and $42 \%$ of that of children Roos et al., (2007 c). Furthermore, the composition of iron in fish is different from that in plant-source foods, containing large amounts of haem iron and a high molecular sub-pool of complex- bound non-haem iron, with a higher bioavailability than non-haem iron.

\section{Zinc}

Gibson et al., (2000) also noted that adding small dried fish to plantbased diets can enhance the content and bioavailability of iron, zinc and calcium. In Malawi, according to the data calculated from the food composition, serving $24 \mathrm{~g}$ of the small dried fish, usipa (Engraulicyprissardella), consumed whole with bones, in a meal, twice a day, can lead to significant increases in iron, zinc, and calcium intakes to meet the needs of children Gibson et al., (2001). Small fish also have many advantages because they can be available for a long period by processing in peak seasons and storing them for year-round consumption, are more affordable for the poor as they are purchased in small portions, and can also be more evenly divided between household members Thilsted et al., (1997).

India is a global biodiversity hotspot and harbours more than 10 percent of the global fish diversity and thereby has the potential to meet the daily requirement of the essential nutrients for human health and can also provide food and nutritional security. Fish is a good source of majority of nutrients, except carbohydrates, for vast majority of population in developing and underdeveloped world to combat protein calorie malnutrition and micronutrient deficiency. The Indian subcontinent constitutes about 1/5th (20\%) of the world's population. Feeding billions with adequate nutritious food in an environmentally sustainable manner is a major challenge which is aggravated with decreasing agricultural land hold. In this scenario, alternate resources for augmenting food production are being searched and exploring the possibility of using water as a major source of food production has gained much attention. In a global fight against over-nutrition, obesity and associated 
ailments, identification and consumption of healthier food than processed red meat products and fast-foods is crucial. Fish and seafood products appear as the healthier alternative animal products and the present paper highlight their nutritional merits and health attributes in a world where malnutrition but also under-nutrition is still negatively affecting the health and well- being of many people.

\section{References}

Ackman, R., Fatty Acids, in Marine Biogenic Lipids, Fats, and Oils, Vol. 1, Ackman R, ed, CRC Press, Boca Raton, FL, 1989, 103.

Ali SSR, Abdhakir ES, Muthukkaruppan R, Sheriff MA, Ambasankar K. Nutrient Composition of Some Marine Edible Fish Species from Kasimedu Fish Landing Centre, Chennai (TN), India. International Journal of Biological Innovations. 2020; 2(2):165-173. https://doi.org/10.46505/IJBI.2020.221 3

Anon 2017 https://www.delamaris.si/healthydiet/thatfish-are-an-important-sourceof-vitamins-and-minerals.

Balami S, Sharma A, Karn R. Significance of Nutritional value of fish for human health. Malaysian Journal of Halal Research. 2019; 2(2): 32-34. DOI: 10.2478/mjhr2019-0012

Barber LB, Keefe SH, Antweiler RC, Taylor HE, Wass RD. 2006. Accumulation of contaminants in fish from wastewater treatment. Environ Sci Technol. 40(2): 603-611. doi: 10.1021/es0514287

Bene, C., Macfayden, G., and Allison, E.H. (2007). Increasing the contribution of small-scale fisheries to poverty alleviation and food security. FAO Fisheries Technical Paper no. 481, FAO, Rome
Berbert, A. A., Kondo, C. R., Almendra, C. L., Matsuo, T., and Dichi, I. (2005). Supplementation of fish oil and olive in patients with rheumatoid arthritis. Nutrition, 21(2), 131-136.

Bogard JR, Thilsted SH, Marks GC, Wahab MA, Hossain MA, Jakobsen J, Stangoulis J. 2015. Nutrient composition of fish species in Bangladesh and potential contribution to recommended nutrient intakes. $J$ Food Compost Anal. 42:120-133. doi:10.1016/j.jfca.2015.03.002

Bucher HC, Hengstler PSC, Meier G. Polyunsaturated fatty acids in coronary heart disease: a meta-analysis of randomized controlled trials. American Journal of Medicine. 2002; 112:298304.

Calder, P.C. (2004). Long chain fatty acids and cardiovascular disease: further evidence and insights. Nutrition Research, 24: 761-772

Calo, L., Bianconi, L., Colivicchi, F., Lamberti, F., Loricchio, M. L., de Ruvo, E., et al., (2005). Fatty acids for the prevention of atrial fibrillation after coronary artery bypass surgery: A randomized, controlled trial. Journal of the American College of Cardiology, 45(10), 1723-1728.

Caygill CPJ, Hill MJ. Fish, n-3 fatty-acids and human colorectal and breast-cancer mortality. European Journal of Cancer Prevention. 1995; 4:329-332.

Connor, W. E. (2000). Importance of n 3 fatty acids in health and disease. American Journal of Clinical Nutrition, 71, 171175.

Damsgaard CT, Lauritzen L, Kjaer TMR, Holm PMI, Fruekilde MB, Michaelsen $\mathrm{KF}$ et al., Fish oil supplementation modulates immune function in healthy infants. The Journal of Nutrition. 2007; 137:1031-1036. 
Davis JA, Ross J, Fairey R, Roberts C, Ichikawa G, Negrey J, Crane D. 2004. Cisnet technical report: contaminant accumulation in forage fish. Oakland, California: San Francisco Estuary Institute. p. 12. Contribution No. 413, June 30th, 2004.

Erkan N, Bilen G. Effect of essential oils treatment on the frozen storage stability of chub mackerel fillet. Journal fur Verbraucherschutz und Lebensmittelsicherheit. 2010; 5(1):101-110

Escher BI, Stapleton HM, Schymanski EL. 2020. Tracking complex mixtures of chemicals in our changing environment. Science. 367(6476):388392. doi: $10.1126 /$ science. aay6636

FAO, FAO Food and Nutrition paper manuals of food quality control food analysis: quality, adulteration and tests of identity. Food and Agriculture Organization of the United Nations, Rome, Italy, 1986.

FAO. (2014). The State of World Fisheries and Aquaculture. (2014). Food and Agriculture Organization of the United Nations, Rome

FAO. 2018. The state of world fisheries and aquaculture 2018 - meeting the sustainable development. goals. Rome: FAO. p. 210.

Food and Agriculture Organization (FAO). 2020a. FAOSTAT - food balance sheets. Rome: FAO, Statistics Division.

Fukuda K. 2015. Food safety in a globalized world. Bull World Health Organ. 93(4):212-212. doi:10.2471/BLT.15. 154831

Gibson, R. S., Hotz, C., Temple, L., Yeudall, F., Mtitimuni, B., Ferguson, E. (2000). Dietary strategies to combat deficiencies of iron, zinc, and vitamin A in developing countries: development, implementation, monitoring, and evaluation. Food and Nutrition Bulletin, 21(2), 219 - 231.

Gibson, R. S., Hotz, C. (2001). Dietary diversification/modification strategies to enhance micronutrient content and bioavailability of diets in developing countries, British Journal of Nutrition, 85(2), $159-166$

Giri, S.S., Paul, B.N., Sahoo, S.K., Rangacharyulu, P.V., Rath, S.C., and Mohanty, S.N. (2010). Fish oils and cardio vascular health. Fishing Chimes, 30(2): 37-39

Graham, I. A., Larson, T., and Napier, J. A. (2007). Rational metabolic engineering of transgenic plants for biosynthesis of omega-3 polyunsaturates. Current Opinion of Biotechnology, 18, 142147

Holben DH, Smith AM. The diverse role of selenium within seloproteins: A review. Journal of the American Dietetic Association. 1999; 99:836-843

Holick MF, Chen TC. Vitamin D deficiency; a worldwide problem with health consequences. The American Journal of Clinical Nutrition. 2008; 871:10801086.

Holick MF. "Diabetes and the Vitamin D connection". Current Diabetes Reports. 2008 a; 8:393-398.

Holick MF. The vitamin D deficiency pandemic and consequence for nonskeletal health: Mechanisms of action. Molecular Aspects of Medicine. 2008 b; 29:361- 368.

Johnson AC, Jin X, Nakada N, Sumpter JP. 2020. Learning from the past and considering the future of chemicals in the environment. Science. 367(6476): 384-387. doi:10. 1126/science.aay663 7.

Klumpp DW, Huasheng H, Humphrey C, Xinhong W, Codi S. 2002. Toxic contaminants and their biological effects in coastal waters of Xiamen, 
China.: I. Organic pollutants in mussel and fish tissues. Mar Pollut Bull. 44(8): 752-760. doi:10.1016/S0025326X(02)00053-X

Kris-Etherton, P.M., and Harris, W.S. (2002). Fish consumption, Fish oil, Omega 3fatty acids and cardiovascular disease. Circulation, 106: 2747-2757

Kumar A, Bajpeyee AK, Yadav CB. Effects of Dietary vitamin-C on Biochemical and Morphometric parameters of Labeorohita. International Journal of Biological Innovations. 2020; 2(2):174-177. https://doi.org/10.46505/IJBI.2020.221 4

Kwasek K, Thorne-Lyman AL, Phillips M. 2020. Can human nutrition be improved through better fish feeding practices? A review paper. Crit Rev Food SciNutr. 25: 1-14.

Lall, S.P. 2002. The minerals. In: Fish Nutrition. J.E. Halver and R.W. Hardy (eds.), 3rd edition. London: Academic Press. pp. 259-308.

Larsen, T., Thilsted, S. H., Kongsbak, K., Hansen, M. (2000). Whole small fish as a rich calcium source. British Journal of Nutrition, 83, 191 - 196.

Michaelsen, K. F., Hoppe, C., Roos, N., Kaestel, P., Stougaard, M., Lauritzen, M. C., Girma, T., Friis, H. (2009). Choice of foods and ingredients for moderately malnourished children 6 months to 5 years of age, Food and Nutrition Bulletin, vol.30 (3), S343404

Mohan Dey M, Rab MA, Paraguas FJ, Piumsombun S, Bhatta R, FerdousAlam M, Ahmed M. 2005. Fish consumption and food security: a disaggregated analysis by types of fish and classes of consumers in selected Asian countries. Aquacult Econ Manage. 9(1-2):89-111. doi:10. 1080/13657300590961537
Mohanty, B.P., Ganguly,S., Mahanty,A., Sankar, T.V., Anandan, R. Chakraborty, K., Paul, B.N., Sarma, D., Dayal, J.S., Venkateshwarlu, G., Mathew, S., Asha, K.K., Karunakaran, D., Mitra, T., Banerjee, S., Chanda, S., Shahi, N., Das, P., Das P., Akhtar, M.S., Vijayagopal, P., and Sridhar, N. (2016). DHA, EPA content and Fatty acid Profile of 39 Food Fishes from India. Biomedical Research International, pp.1-14. Doi./org/10.1155/2016/4027437

Mohanty, B.P., Sankar, T.V., Ganguly, S., Mahanty, A., Anandan, R. Chakraborty, K., Paul, B.N., Sarma, D., Dayal, J., Venkateshwarlu, G., Mathew, S., Asha, K.K., Mitra, T., Karunakaran, D., Chanda, S., Shahi, N., Das, P., Das P., Akhtar, M.S., Vijayagopal, P., and Sridhar, N. (2016a). Micronutrient composition of 35 food fishes from India and their significance in human nutrition. Biological Trace Element Research, $174 \quad$ (2), 448-458. DOI 10.1007/s12011-016-0714-3

Mohanty, B.P., Ganguly, S., Mahanty, A., Mitra, T., Patra, S., Karunakaran, D., Mathew, S., Chakraborty, K., Paul, B.N., Sarma, D., Dayal, S., Singh, S., and Ayyappan, S. (2019). Fish in Human Health and Nutrition. p 189218. In B.P. Mohanty (ed.) Advances in Fish Research, Narendra Publishing House, New Delhi,

Morales M, Hogaldo F, Sevenich R. Fatty acids profile in canned tuna and sardine after retrosterilization and high-pressure thermal sterilization treatment. Journal of food and Nutrition Research. 2015; 54(2):171178.

Nargis, A. (2006). Seasonal variation in the chemical composition of body flesh of Koi fish, Anabas testudineus (Bloch), 
(Anabantidae: Perciformis). Bangladesh Journal ofScientific and Industrial Research, 41: 219-226

Pal J, Shukla BN, Maurya AK, Verma HO. A review on role of fish in human nutrition with special emphasis fatty acid. International Journal of Fisheries and Aquatic Studies. 2018; 6(2):427-430.

Paul, B.N., Chanda, S., Sridhar, N., Saha, G.S., and Giri, S.S. (2016). Fatty acid, Amino acid and Vitamin composition of Indian Catfish, Magur (Clarias batrachus) and Singhi (Heteropneus tesfossilis).SAARC Journal of Agriculture, $\quad 14(2)$ : $\quad 189-$ 199.Doi./org/10.3329/sja.v14i2.31258

Paul, B.N., Chanda, S., Sridhar, N., Saha, G.S., and Giri, S.S. (2015). Proximate and mineral composition of Magur (Clariasbatrachus) and Singhi (Heteropneustesfossilis). Indian Journal of Animal Nutrition, 32(4):453-456.doi: $\quad$ 10.5958/22316744.2015.00017.1

Paul, B.N., Bhowmick, S., Chanda, S., Sridhar, N., and Giri, S.S. (2019). Nutrient Profile of Some Freshwater Fish Species. Pp 12. In Proc. Golden Jubilee International Conference on "Trends in Zoology". 03-04 Jan., 2019. The University of Burdwan, Burdwan, India

Pawar SM, Sonawane SR. Fish muscle protein highest source of energy. International Journal of Biodiversity and Conservation. 2013; 5(7):433-435. https://doi.org/ 10.5897/IJBC12.043.

Pond, C. M. (1998). The fats of life. Cambridge, United Kingdom: Cambridge University Press

Roos, N. (2001). Fish consumption and aquaculture in rural Bangladesh: Nutritional contribution and production potential of culturing small indigenous fish species (SIS) in pond polyculture with commonly cultured carps. Ph.D. Thesis, Department of Human Nutrition, The Royal Veterinary and Agricultural University, Denmark

Roos, N., Chamnan, C., Loeung, D., Jakobsen, J., Thilsted, S. H. (2007c). Freshwater fish as a dietary source of vitamin A in Cambodia. Food Chemistry, 103 (4): $1104-1111$.

Sanchez-Alonso, I., Jimenez-Escrig, A., Saura-Calixto, F., and Borderias, A.J. (2007). Effect of grape antioxidant dietary fibre on the prevention of lipid oxidation in minced fish: Evaluation by different methodologies. Food Chemistry, 101: 372-378

Sargent, J.R. (1997). Fish oils and human diet. British Journal of Nutrition, 78: Suppl.1,S5- S13

Simopoulos A. Nutritional aspects of fish, in Seafood From Producer to Consumer, Integrated Approach to Quality, Luten, J., Borrensen, T., and Oehlenschlager, J., eds., Elsevier Science, London, U.K., 1997, 589.

Sinn N. Physical fatty acid deficiency signs in children with ADHD symptoms. Prostaglandins, Leukotrienes and Essential Fatty Acids. 2007; 77:109115.

Srivastava R, Srivastava N. Changes in nutritional value of fish Channa punctatus after chronic exposure to zinc. J. Environ. Biol. 2008; 29(3):299-302.

Sujatha K, Joice AA, Senthilkumaar P. Total protein and lipid content in edible tissues of fishes from Kasimodu fish landing centre, Chennai, Tamil Nadu. European Journal of Experimental Biology. 2013; 3(5): 252-257.

Tacon AGJ, Metian M. 2013. Fish Matters: importance of aquatic foods in human and global food supply. Rev Fish Sci. 21(1):1-17. 
Thilsted SH, James D, Tippe J, Subasinghe R, and I. Karunasagar. 2014. Paper Presented at the FAO/WHO ICN2 Second International Conference on Nutrition - Better Nutrition Better Lives, 19-21 November 2014, Rome, Italy. p. 15

Thilsted, S. H., Roos, N., Hassan, N. (1997). The role of small indigenous fish species in food and nutrition security in Bangladesh. World Fish Centre Quarterly, July-December (Supplement), $82-84$.

US Department of Agriculture (USDA). 2018. Composition of Foods: raw, processed, prepared. USDA National Nutrient Database for Standard Reference, Legacy April 2018, Slightly revised July 2018.

Venkatraman S Chezhian. Proximate composition of different fish species collected from Muthupet mangroves. International Journal of Fisheries and Aquatic Studies. 2015; 2(6):420-423

Venugopal V. Methods for processing and utilization of low cost fishes: A critical appraisal. Journal of Food Science \& Technology. 1995; 32:1-12.

Verma AK, Prakash S. Status of Animal Phyla in different Kingdom Systems of Biological Classification. International Journal of Biological Innovations.
2020; 2(2):149-154. https://doi.org/10. 46505/IJBI.2020.2211

Vitenskapskomiteen (VKM). 2014. Benefitrisk assessment of fish and fish products in the Norwegian diet - an update. Scientific Opinion of the Scientific Steering Committee. VKM Report 15. Oslo, Norway. p. 293. ISBN: 978-82-8259-159-1.

Wolk, A., Larsson, S. C., Johansson, J. E., \& Ekman, P. (2006). Long-term fatty fish consumption and renal cell carcinoma incidence in a population-based prospective cohort of women. The Journal of the American Medical Association, 296, 1371-1376.

Xanthos D, Walker TR. 2017. International policies to reduce plastic marine pollution from single-use plastics (plastic bags and microbeads): A review. Mar Pollut Bull. 118(1-2):1726. doi:10.1016/j.marpolbul.2017. 02.048

Zhong VW, Van Horn L, Greenland P, Carnethon MR, Ning H, Wilkins JT, Lloyd-Jones DM, Allen NB. 2020. Associations of processed meat, unprocessed red meat, poultry, or fish intake with incident cardiovascular disease and all-cause mortality. JAMA Intern Med. 180(4): 503-512. doi:10.1001/jamainternmed.2019.6969

\section{How to cite this article:}

Pooja Badoni, Iqra Nazir, Merenlong Aier, Puspendu Bikash Maity, Subhadeep Samanta and Animesh Das. 2021. Significant Role of Fish Nutrients with Special Emphasis to Essential Fatty Acid in Human Nutrition. Int.J.Curr.Microbiol.App.Sci. 10(02): 2034-2046. doi: https://doi.org/10.20546/ijcmas.2021.1002.243 